\section{PERAN KEJAKSAAN DALAM PENGAMANAN DAN PENDAMPINGAN HUKUM PROYEK STRATEGIS SESUAI UNDANG UNDANG NO 16 TAHUN 2004 TENTANG KEJAKSAAN REPUBLIK INDONESIA ${ }^{1}$ \\ Oleh: La Haja ${ }^{2}$ \\ Devy K. G. Sondakh ${ }^{3}$ \\ Natalia L. Lengkong ${ }^{4}$}

\begin{abstract}
ABSTRAK
Penelitian ini digunakan adalah Metode
\end{abstract} Penelitian Hukum Normative. Dengan menggunakan beberapa pendekatan, seperti pendekatan peraturan perundang-undangan (statute approach), pendekatan Konseptual (conceptual approach), dan pendekatan kasus (case approach). Penelitian ini menemukan bahwa adanya beberapa proyek strategis yang di proses secara hukum baik oleh aparat penegak hukum Kejaksaan R.I, Kepolisian dan KPK akibat pengguna anggaran dan PPK (pejabat Pembuat Komitmen) di Instansi Pemerintan baik Pusat/Daerah telah melakukan pembayaran $100 \%$ kepada penyedia jasa/kontraktor yang tidak sesuai ketentuan dalam peraturan perundangundangan akibatnya proyek tersebut tidak bisa di manfaat/digunakan yang menyebabkan terjadinya kerugian negara.Bahwa menyikapi permasalahan tersebut maka aparat penegak hukum Kejaksaan R.I tidak lagi menggunakan fungsinya sebagai penyelidik/penyidik namun berubah fungsi menjadi pengawal,pengaman dan pendamping hukum terhadap proyek strategis lewat fungsi pencegahan (preventif) yaitu dengan melakukan penyuluhan hukum terhadap penyelenggara proyek baik berkaitan dengan aturan-aturan hukum yang berkaitan dengan pengadaan barang dan jasa serta aturan-aturan yang berkaitan dengan masalaha keuangan..

Kata Kunci: Peran, Kejaksaan, Pengamanan, Proyek Strategis

\footnotetext{
${ }^{1}$ Artikel Tesis.

${ }^{2}$ Mahasiswa pada Pascasarjana Unsrat, Manado. NIM. 17202108024

${ }^{3}$ Fakultas Hukum Unsrat, Doktor IImu Hukum

${ }^{4}$ Fakultas Hukum Unsrat, Doktor IImu Hukum
}

\section{PENDAHULUAN}

\section{A. Latar Belakang Masalah}

Perkembangan pembangunan yang begitu cepat dengan hadirnya berbagai mega proyek di daerah seperti jalan tol/ jalan layang, gedung bertingkat dengan sistem kondominium bandar udara dan lain sebagainya merupakan indikator kemajuan pertumbuhan ekonomi sekaligus berpotensi terjadinya korupsi baik oleh pihak pemerintah maupun swasta kehadiran mega proyek strategis nasional didaerah merupakan suatu hal yang signifikan dalam pembangunan daerah atau tepatnya dalam menggerakkan roda perekonomian yang dilakukan pemerintah daerah.

Undang undang nomor 2 Tahun 2017 telah mengatur tentang aspek hukum tentang jasa konstruksi dalam kegiatan Pembangunan baik jalan jembatan dan gedung. Terkait dengan mega proyek strategis nasional presiden telah mengeluarkan Perpres Nomor 58 Tahun 2017 Tentang Proyek Strategis Nasional. Hasil jasa konstruksi berupa bangunan dan prasarana lainya yang berfungsi untuk meningkatkan pertumbuhan ekonomi nasional ${ }^{5}$ Percepatan pembangunan infrastruktur terus dilakukan pemerintah di segala bidang dengan dukungan pendanaan negara dan investasi dari luar negeri. Dasar hukum Proyek Startegis Nasional yaitu Peraturan Presisiden Nomor 58 Tahun 2017 tentang Percepatan Pelaksanaan Proyek Strategis Nasional, total ada 247 proyek/program strategis nasional. Proyekproyek itu ditujukan, terutama untuk pembangunan infrastruktur jalan (30\%) dan selebihnya untuk pembangunan pelabuhan, bandar udara, bendungan, irigasi, kereta api, energi, pengolahan air, proyek smelter, perumahan, pos lintas batas negara, kelautan, tanggul laut, kelistrikan dan industri pesawat.

Pengamanan Pembangunan Proyek strategis merupakan Tugas dari Kejaksaan Republik Indonesia dalam bidang Intelijen dalam penegakan hukum untuk di daerah di namakan Tim PPS ( Pengaman Proyek Strategis) hal tersebut sebagaimana diatur dalam Peraturan Jaksa Agung Republik

\footnotetext{
5 Abdulkadir Muhamad. 2010.Hukum Perusahan Indonesia. Cetakan Ketiga. Bandung: Cv Citra Adytia Bhakti. 585
} 
Indonesia Nomor PER-006/A/JA/07/2017 Tentang Organisasi Tata Kerja Kejaksaan Agung R.I di mana sebelumnya tim Pengawal dan Pengaman untuk di daerah di namakan TP4D sesuai dengan kriteria yang diatur dalam Peraturan Kejaksaan Republik Indonesia Perja Nomor - 014/A/Ja/11/2016 dan Tim TP4D ini telah dibubarkan pada Tahun 2019 tetapi fungsi Kejaksaan dalam pengawalan dan pengamanan proyek tetap dijalankan yang melekat pada fungsi penegakan hukum Kejaksaan Republik Indonesia. Proyek strategis nasional didasarkan pada Rencana Pembangunan Jangka Menengah (RPJM) Pemerintah yang berbasis Nawacita atau dengan Rencana Pembangunan Jangka Panjang (RPJP) Nasional Indonesia 2005-2025 sesuai dengan UU No. 17/2007. Dalam RPJP ditegaskan arah pembangunan ekonomi 2025 ditujukan untuk mewujudkan perekonomian yang maju, mandiri dan mampu secara nyata memperluas peningkatan kesejahteraan masyarakat,mengacu pada RPJP tersebut dapat disimpulkan tujuan akhir dari proyek strategis nasional ini adalah mengantarkan kita kepada suatu keadaan yang ditunjukkan dengan meningkatnya kesejahteraan rakyat dengan landasan pengaturan tersebut maka keberadaan Proyek Staegis Nasional mempunyai dasar dan kepastian hukum.

Pasal 33 Undang Undang Dasar 1945 yang merupakan landasan konstituonal yang menjadi dasar bagi pemerintah melakukan percepatan pembangunan dan pertumbuhan ekonomi nasional untuk mewujudkan kesejahteraan masyarakat, dengan demikian kehadiran infrastruktur harus dipandang sebagai dorongan untuk menciptakan pertumbuhan ekonomi serta meningkatkan kesejahteraan masyarakat.Pembangunan sarana dan prasarana baik gedung jalan dan jembatan yaitu masyarakat dan pemerintah bukan pemilik modal atau perusahan. Negara hukum dan keadilan bagaikan dua sisi mata uang, keduanya berbeda tetapi tidak dapat dipisahkan satu sama lain. Keadilan merupakan tujuan sekaligus kondisi yang harus diwujudkan serta merupakan jaminan dalam setiap negara yang menyatakan dirinya sebagai negara hukum. Sebagaimana pula Indonesia yang secara yuridis konstitusional telah menyatakan dirinya sebagai negara hukum, yakni Pasal 1 ayat (3) Undang- Undang Dasar Tahun 1945 yang berbunyi, "Negara Indonesia adalah negara hukum". 1 Secara historis pun, jauh sebelum termuat dalam UUD 1945 (perubahan), negara hukum (rechtsstaat) ${ }^{6}$ adalah negara yang diidealkan oleh para pendiri bangsa (founding fathers) sebagaimana dituangkan dalam Penjelasan Umum UUD 1945 sebelum perubahan tentang sistem pemerintahan negara yang menyatakan bahwa "Negara Indonesia berdasar atas hukum (rechtsstaat), tidak berdasarkan kekuasaan belaka (machtsstaat)". ${ }^{7}$ Namun demikian, fenomena penegakan hukum yang terjadi di Indonesia kini justru menunjukkan realita yang bertolak belakang dari hal tersebut. Ironi dalam penegakan hukum, hukum dinilai "tajam ke bawah, tumpul ke atas". Itulah ungkapan yang banyak digunakan, setidaknya oleh media massa, untuk mengilustrasikan kondisi penegakan hukum di Indonesia. Hukum begitu tegas. ditegakkan kepada masyarakat kecil di sisi lain, hukum begitu lentur dan sulit untuk ditegakkan ketika yang tersangkut masalah hukum adalah orang-orang yang dapat menjangkau kekuasaan dan para pemodal.

Untuk memulihkan kepercayaan masyarakat terhadap hukum maka Kejaksaan akan menindak setiap pelaku korupsi termasuk dalam mega proyek. Dengan tidak memandang bulu. Prinsip persamaan di hadapan hukum (equality before the law) sehingga dalam penegakan hukum Kejaksaan akan menindak siapapun yang melanggar hukum yang melakukan korupsi tanpa melihat kedudukan dan jabatannya. Untuk menjaga kepercayaan masyarakat aparat penegak hukum akan dapat berlaku adil dan tidak memihak (obyektif). ${ }^{8}$ Janedjri M Gaffar, Budaya Hukum dalam Penegakan Hukum, dalam http://nasional.sindonews.com/read/2012/12/ 27/18/701184/budaya hukum dalam

\footnotetext{
${ }^{6}$ Sri Soemantri.1992. Bunga Rampai Hukum Tata Negara Indonesia. Cetakan Ketiga. Bandung:Alumni. 27

${ }^{7}$ Harun Alrasid. 2007.Judul Naskah Undang-Undang Dasar 1945 Sesudah Empat Kali Diubah oleh MPR. Cetakan pertama. Jakarta: UI Press. hal 4

${ }^{8}$ M Gaffar.2003.Budaya Hukum dalam Penegakan Hukum. Cetakan pertama. Bandung: Sinar Grafika. 55
} 
penegakan hukum, diakses pada tanggal 26 Febr 2012.

Disinilah peran pengawasan kejaksaan terhadap proyek strategis nasional agar tidak terjadi korupsi dari evaluasi menyeluruh proyek-proyek tersebut, yaitu menghadirkan keadilan ekonomi dan sosial terasa nyata dalam kehidupan rakyat Pembangunan infrastruktur yang terus berkembang baik di pusat maupun daerah merupakan wujud dari kemajuan ekonomi yang terus meningkat. Instruksi Presiden Nomor 7 Tahun 2015 merupakan titik awal dari pengaturan secara nasioal tentang aksi pencegahaan dan pemberantasan korupsi diberbagai bidang pembangunan .Perpres ini merupakan titik tolak Lahirnya Tim Pengawalan dan Pengamanan Pembangunan Daerah (TP4D) baik di pusat maupun daerah pada tahun tahun $2015 \mathrm{~s} / \mathrm{d}$ pertengahan tahun 2019 yang lalu dan berdasarkan Keputusan Jaksa Agung RI Nomor : 345 Tahun 2019 tentang pencabutan Keputusan Jaksa Agung Nomor :152/A/JA/10/2015 tentang pembentukan Tim Pengawal dan Pengamanan Pemerintahan dan Pembangunan Kejaksaan Republik Indonesia sebagaimana telah di rubah dengan Keputusan Jaksa Agung R.I Nomor :-KEP-059/A/JA/2018 tentang perubahan atas keputusan Jaksa Agung Nomor KEP- 152/A/JA/10/2015 tentang pembentukan Tim Pengawal dan Pengaman Pemerintahan dan Pembangunan.

Pengawalan proyek strategis nasional oleh Kejaksaan didasarkan pada Undang Undang Kejaksaan Nomor 16 Tahun 2004 dan Peraturan Presiden Nomor 29 tahun 2016 Susunan dan Organisasi Kejaksaan Republik Indonesia dan Peraturan Jaksa Agung R.I Nomor: PER-006/A/JA/07/2017 Tentang Organisasi Tata Kerja Kejaksaan Agung R.I dalam hal pengamanan Proyek Strategis Nasional tetap melekat Jabatan Direktur Pengamanan Proyek Strategis Nasional yaitu Direktur D pada Jaksa Agung Muda Intelijen hal tersebut dalam Pasal 223 ada Jabatan Direktorat Pengamanan Pembangunan Strategis (Direktur D) salah satu tugasnya yaitu melaksanakan perumusan kebijakan kegiatan intelijen, dan operasi intelijen yang berkaitan dengan bidang pengamanan pembangunan strategis, selanjutnya berdasarkan Pasal 444 PER-006/A/JA/07/2017 Tentang Organisasi
Tata Kerja Kejaksaan Agung R.I yang menyatakan salah satu ruang lingkup di Bidang Perdata dan Tata Usaha Negara meliputi Penegakan hukum, bantuan hukum, pertimbangan hukum dan tindakan hukum lainnya kepada negara atau pemerintah meliputi lembaga atau badan negara, lembaga atau instansi pemerintah dan daerah, Badan Hukum Milik Negara (BUMN) atau Daerah (BUMD) di bidang Perdata dan Tata Usaha Negara untuk menyelamatkan,memulihkan kekayaan negara, menegakan kewibawaan pemerintah dan negara serta memberikan pelayanan hukum kepada masyarakat, sehingga dalam pendampingan hukum terhadap pelaksanaan Proyek itu merupakan tugas dan wewenang Bidang Perdata dan Tata Usaha Negara selain itu dalam Pasal 30 ayat (2) Undang-undang Nomor 16 tahun 2006 tentang Kejaksaan Republik Indonesia berbunyi di bidang perdata dan Tata Usaha Negara, Kejaksaan dengan kuasa khusus dapat bertindak baik di dalam maupun di luar pengadilan untuk dan atas nama negara atau pemerintah, selain itu juga dalam Pasal 30 ayat (3) huruf a yang menyatakan bahwa "Dalam bidang ketertiban dan ketentraman umum kejaksaan turut menyelenggarakan kegiatan peningkatan kesadaran hukum bagi masyarakat, maka terhadap terhadap pelaksanaan Proyek Strategis Nasional (PSN) sebagaimana tercantum dalam Peraturan Presiden(Perpres) Nomor 58 tahun 2017. Perpres ini merupakan perubahan dari Perpres Nomor 3 Tahun 2016 tentang Percepatan Pelaksanaan Proyek Strategis Nasional yang ditandatangani pada 8 Januari 2016 yang merupakan dasar hukum pelaksanaan proyek strategis nasional. Yang ditunjukkan dengan meningkatnya kesejahteraan rakyat dengan landasan pengaturan tersebut maka keberadaan proyek Staegis Nasional mempunyai dasar dan kepastian hukum. ${ }^{9}$

\section{B. Rumusan Masalah}

1. Bagaimana peran Kejaksaan dalam Pendampingan hukum di Bidang Perdata dan Tata Usaha Negara dalam

\footnotetext{
${ }^{9}$ Fuady Munir.1996. Hukum Bisnis Dalam Teori dan Praktek. Cetakan pertama. Bandung: Citra Aditya Bakti. 20
} 
pelaksanaan Proyek pembangunan Strategis?

2. Bagaimana bentuk Pengamanan Kejaksaan R.I dalam Proyek Strategis yang dilakukan oleh Bidang Intelijen?

\section{Tujuan Penelitian}

1. Untuk menganalisis bagaimana bentuk Pengamanan dan Pendampingan Hukum Kejaksaan Republik Indonesia dalam pengawasan penyelengaraan Proyek Strategis yang ada di daerah khusunya yang ada di Provinsi Sulawesi Utara ;

2. Untuk mengetahui implikasi atas Pengamanan dan Pendampingan Hukum yang dilakukan Kejaksaan terhadap proyek Starategis Nasional untuk mencegah terjadinya kebocoran anggaran dalam pelaksanaan proyek sebagai bentuk awal terjadinya tindak pidana korupsi ?

\section{METODE PENELITIAN}

\section{A. Jenis/Tipe Penelitian}

Berdasarkan permasalahan yang diteliti oleh penulis, maka metode penelitian yang digunakan adalah Metode Penelitian Hukum Normative. Pengunaan metode ini yaitu meneliti norma yang menjadi dasar pengaturan pengamanan dan pendampingan hukum terhadap Proyek Strategis Nasional dan berbagai implikasi hukumnya. Penelitian ini terfokus pada hukum secara tertulis.

Penelitian hukum normatif atau disebut juga penelitian hukum doktrinal acapkali hukum dikonsepkan sebagai apa yang tertulis dalam peraturan perundang-undangan (Law is books) atau hukum dikonsepkan sebagai kaidah atau norma.

\section{B. Pengumpulan Data}

Bahwa Pengumpulan data yaitu berupa pengumpulan bahan hukum dilakukan lewat perpustakaan, atau bagian perundang undangan kejaksaan Republik Indonesia Undang-undang Nomor 16 tahun 2004 tentang Kejaksaan Republik Indenesia, Peraturan Jaksa Agung Republik Indonesia, Petunjuk Tehnis dari Jaksa Agung Muda Intelijen dan Jaksa Agung Muda Perdata dan Tata Usaha Negara. Pengumpulan bahan hukum Primer, sekunder dan tertier dilakukan pada perpustakan atau melalui internet untuk upload data untuk data penunjang dilakukan pada instansi yang berwenang khusnya Kejaksaan Tinggi Sulawesi Utara.

\section{Pengolahan Data}

Dalam mengolah data didasarkan pada sumber penelitian yaitu bahan hukum berupa Undang undang atau peraturan yang terkait baik dilakukan melalui wawancara dengan koresponden kemudian diolah dan disajikan dalam tesis baik itu diambil dari bahan hukum primer, bahan hukum sekuder dan bahan hukum tertier.

1. Bahan hukum primer yaitu:

Bahan hukum utama yang terkait langsung dengan obyek penelitian yang terdiri dari Undang-undang Kejaksaan Nomor 16 Tahun 2004 tentang Kejaksaan Republik Indonesia, Undang undang Jasa konstruksi dan Undang undang No 31 Tahun 1999 Yunto Undang Undang No 20 Tahun 2001 tentang Tindak Pidana Korupis dan Peraturan Jaksa Agung Republik Indonesia Nomor: PER006/A/JA/07/2017 Tentang Organisasi Tata Kerja Kejaksaan Agung R.I, Surat Edaran Jam Datun Nomor : 02/D/Ds.2/04/2020 tentang Pedoman Pendampingan Hukum Keperdataan dalam Pengadaan Barang dan Jasa serta Petunjuk Teknis dari Jaksa Agung Muda Intelijen Nomor : B-484/D/Dpp/03/2020 Tentang Pelaksanaan Kegiatan Pengamanan Pembangunan Strategis.

2. Bahan hukum sekunder yaitu:

Bahan yang memberikan penjelasan mengenai bahan hukum primer seperti: Buku buku tentang Kejaksaan Pengawasan dan jasa konstruksi, hasilhasil penelitian, jurnal atau pendapat pakar hukum tentang obyek yang diteliti.

3. Bahan hukum tersier yaitu:

Bahan yang memberikan petunjuk maupun pejelasan terhadap bahan hukum primer dan bahan hukum sekunder, seperti kamus (hukum), ensiklopedia. ${ }^{10}$

\footnotetext{
${ }^{10}$ Amiruddin. 2010. Pengantar Metode Penelitian Hukum. Cetakan Ketiga. Jakarta: Rajawali Pers. 118
} 


\section{Analisa Data}

Dalam penulisan ini juga penelitian dilakukan dengan menganalisa data melalui pendekatan undang-undang dan pendekatan kasus. Pendekatan undang-undang dilakukan dengan cara menelaah semua undang-undang dan peraturan yang berhubungan dengan pengamanan dan pendampingan hukum terkait dalam hal perlindungan dan penegakan hukumnya sedangkan pendekatan kasus yaitu terkait dengan tindak pidana yang sedang terjadi.

\section{HASILDANPEMBAHASAN}

\section{A. Peran Kejaksaan dalam Pendampingan hukum di Bidang Perdata dan Tata Usaha Negara dalam pelaksanaan Proyek pembangunan Strategis}

Proyek Strategis Nasional adalah proyek yang dilaksanakan oleh Pemerintah, Pemerintah Daerah, dan/atau badan usaha yang memiliki sifat strategis untuk peningkatan pertumbuhan dan pemerataan pembangunan dalam rangka meningkatkan kesejahteraan masyarakat dan pembangunan daerah. Adapun proyek-proyek yang masuk dalam proyek strategis nasional itu antara lain, proyek pembangunan infrastruktur jalan tol, ${ }^{11}$ proyek jalan nasional atau strategis nasional non-tol, proyek sarana dan prasarana kereta api antarkota, proyek kereta api dalam kota, proyek revitalisasi bandara, pembangunan bandara baru, proyek pembangunan bandara strategis lain, pembangunan pelabuhan baru dan pengembangan kapasitas, program satu juta rumah, pembangunan kilang minyak, proyek pipa gas atau terminal LPG, proyek energi asal sampah, proyek penyediaan infrastruktur air minum, proyek penyediaan sistem air limbah komunal, pembangunan tanggul penahan banjir, proyek pembangunan pos lintas batas negara (PLBN) dan sarana penunjang, proyek bendungan, program peningkatan jangkauan broadband, proyek infrastruktur IPTEK strategis lainnya, Pembangunan kawasan industri prioritas atau kawasan ekonomi khusus, proyek pariwisata, proyek pembangunan smelter, dan proyek pertanian

\footnotetext{
${ }^{11}$ Munir Fuady. 1998. Kontrak Pemborongan Mega Proyek. Cetakan pertama. Jakarta: PT. Citra Aditya Bakti. 122
}

dan kelautan. Dalam Pendampingan hukum yaitu Kejaksaan melaksanakan tugas pendampingan di bidang keperdataan dan Tata Usaha Negara untuk mencegah penyimpangan administrasi yang merugikan negara.terkait dengan korupsi ${ }^{12}$

Peran dan funsi kejaksaan untuk mencegah korupsi mulai dari penyimpangan perjaian atau kontrak secara perdata sampai ke perkara pidana. Aspek lain yang terkait dengan pendampingan hukum yaitu fungsi jaksa sebagai Pengacara Negara dalam penanganan perkara perdata dan tatausaha Negara. Pendampingan hukum bukan hanya dalam perkara perdata saja tetapi dalam perkara Tata Usaha Negara sebagai akibat dari putusan pejabat yang merugikan orang maupun badan hukum. Pendampingan hukum dilakukan Kejaksaan Republik Indonesia setempat baik di Provinsi dan Kabupaten Kotas.berupa sosialisasi dengan cara:

a. Memberikan penerangan hukum di lingkungan instansi pemerintah, BUMN, BUMD, dan pihak lain yang terkait materi tentang perencanaan, pelelangan, pelaksanaan pekerjaan, pengawasan pelaksanaan pekerjaan, perijinan, pengadaan barang dan jasa, tertib administrasi, dan tertib pengelolaan keuangan Negara;

b. Melakukan diskusi atau pembahasan bersama instansi pemerintah, BUMN, BUMD untuk mengidentifikasi permasalahan yang dihadapi dalam penyerapan anggaran dan pelaksanaan pembangunan;

c. Memberikan penerangan hukum dan penyuluhan hukum baik atas inisiatif Tim Pengawalan Pembangunan Daerah, maupun atas permintaan pihak-pihak yang memerlukan yang tempat dan waktu pelaksanaan ditetapkan berdasarkan kesepakatan dan sesuai kebutuhan;

d. Kejaksaan juga dapat melibatkan instansi atau pihak lain yang memiliki kapasitas, kompetensi dan relevan dengan materi penerangan hukum yang akan

\footnotetext{
${ }^{12}$ Arsyad Jawada Hafids. 2003. Korupsi dalam Perspektif Hukum Administrasi Negara. Cetakan Jakarta: Pertama Sinar Grafika. Cetakan Pertama. 10
} 
disampaikan kepada instasi pemerintah, BUMN, dan BUMD.

Pendampingan hukum juga merupakan wacana tentang pemberantasan korupsi sudah sedemikian mengkhawatirkan karena lebih banyak anggota masyarakat yang pesimistis dibandingkan dengan mereka yang optimistis. Sikap sebagian besar aparat dan pejabat pemerintahan serta pimpinan elit politik dan masyarakat yang memperlihatkan kecenderungan untuk membiarkan saja berlangsungnya kegiatan korupsi, meskipun sudah mencapai tahap yang membahayakan bangsa dan negara, merupakan tanda-tanda mulai terjadinya degenerasi dalam pemikiran dan jati diri kita sebagai bangsa yang mampu mengatur kehidupan bangsa dan negaranya serta memajukan kesejahteraan rakyatnya. Pemberantasan tindak pidana korupsi adalah serangkaian tindakan untuk mencegah dan memberantas tindak pidana korupsi melalui upaya koordinasi, supervise, monitor, penyelidikan, penyidikan, penuntutan, dan pemeriksaan di sidang pengadilan, dengan peran serta masyarakat berdasarkan peraturan perundang-undangan yang berlaku.

Pada prinsipnya fungsi pendampingan dan pengawalan pembangunan tetap dijalankan walaupun sudah tidak ada T4D untuk mencegah penyimpangan dan korupsi.Keputusan Jaksa Agung RI Nomor : Kep152/A/JA/10/2015 tentang Pembentukan TP4 yang sudah dibubarkan berdasarkan berdasarkan Keputusan Jaksa Agung RI Nomor : 345 Tahun 2019 tentang pencabutan Keputusan Jaksa Agung Nomor :152/A/JA/10/2015 tentang pembentukan Tim Pengawal dan Pengamanan Pemerintahan dan Pembangunan Kejaksaan Republik Indonesia sebagaimana telah di rubah dengan Keputusan Jaksa Agung R.I Nomor :-KEP-059/A/JA/2018 ${ }^{13}$ tentang perubahan atas keputusan Jaksa Agung Nomor KEP- 152/A/JA/10/2015 tentang pembentukan Tim Pengawal dan Pengaman Pemerintahan dan Pembangunan, terkait dengan pendampingan hukum untuk

13 Keputusan Jaksa Agung RI Nomor : Kep152/A/JA/10/2015 tentang Pembentukan Tim Pengawal dan Pengaman Pemerintahan dan Pembangunan Kejaksaan RI, TP4 yang sudah dibubarkan berdasarkan berdasarkan Keputusan Jaksa Agung RI Nomor : 345 Tahun 2019 pencegahan korupsi,walaupun Tim ini sudah dibubarkan pada tahun 2019 tetapi tugas dan fungsinya dalam pencegahan korupsi harus terus dilanjutkan oleh Kejaksaan sebagai penegak hukum. Pendampingan secara perdata adalah upaya pencegahan tindak pidana korupsi yang efisien dan efektif dapat dilakukan dengan 4 (empat) pendekatan atau strategi yaitu: 1. Pendekatan hukum; 2. Pendekatan budaya 3. Pendekatan ekonomi 4. Pendekatan sumber daya manusia dan sumber daya keuangan. Melalui pendekatan hukum, pemerintah telah menggulirkan berbagai peraturan perundang-undangan sebagai dasar pemberantasan tindak pidana korupsi di Indonesia. Untuk itu, yang perlu dilakukan adalah memaksimalkan hal-hal yang telah dicantumkan dalam berbagai ketentuan yang ada tersebut, serta melakukan evaluasi terhadap aturan-aturan yang ada guna meningkatkan keberhasilan tujuan yang diharapkan.

Dengan prinsip-prinsip yang dijamin dalam Undang Undang kejaksaan, ini, semestinya kehadiran Tim kejaksaan bidang Intelijen dan Pendampingan Hukum Bidang Perdata Tata Usaha Negara dalam melakukan pengamanan dan pendampingan hukum/legal openium mampu melahirkan rasa aman dan keleluasaan aparatur pemerintah dalam menjalankan tugasnya untuk itu menjadi penting para pihak memahami ruang lingkup tugas dan fungsi dari Tim PPS dan Bidang Perdata Tata Usaha Negara dalam melakukan pendampingan hukum dalam proyek proyek terkait ketaatan pada kontrak konstruksi yang disepakati ${ }^{14}$.

Bahwa bidang Perdata Tata Usaha Negara mengawal dan mengamankan disisi hukumnya, sementara itu pemohon tetap leluasa melaksanakan manajemen dan teknis pengadaan barang/jasa. Jika sebelum bentuk pelayanan kejaksaan hanya pendampingan hukum melalui layanan Perdata dan Tata Usaha Negara maka dengan Pengawalan dan pendampingan kejaksaan maka pelayanan semakin lengkap dengan pemberian pendapat, penerangan dan penyuluhan hukum.

Tahapan pengadaan barang/jasa obyek pengawalan dan pengamanan harus tertuang

\footnotetext{
${ }^{14}$ Yasin. Nazarkhan. 2006. Mengenal Kontrak Konstruksi di Indonesia. Cetakan pertama. Jakarta: PT Gramedia Pustaka Utama. 43
} 
dalam kesepakatan bersama antar para pihak. Sesuai dengan Perpres 54/2010 pasal 33 tahapan utama pengadaan barang/jasa pemerintah adalah Persiapan Pengadaan, Pelaksanaan Pemilihan Penyedia, ${ }^{15}$ Persiapan dan Pelaksanaan Kontrak dan Serah Terima Pekerjaan, kelibatan Bidang Perdata dan Tata Usaha Negara dalam tahapan pengadaan cukup efektif dalam tahapan berikut:

1. Pada tahap persiapan pelaksanaan pemilihan penyedia. Dilakukan pembahasan Rencana Umum Pengadaan (RUP), Rencana Pelaksanaan Pengadaan (RPP) dan Rencana Pemilihan Penyedia dengan output akhir Rancangan Dokumen Pemilihan Penyedia. Tim PA/KPA, PPK dan Pokja mengidentifikasi potensi risiko-risiko hukum yang akan dihadapi untuk dimintakan pendapat hukum Tim PPS Intelijen dan Bidang Perdata dan Tata Usaha Negara.

2. Pada tahap Pelaksanaan Pemilihan Penyedia, Tim PPS dan Perdata dan Tata Usaha Negara mendapatkan laporan secara berkala. Terkecuali dalam proses Pokja meminta pendapat hukum dalam pengambilan putusan. Dengan demikian Bidang Perdata dan Tata Usaha Negara tidak diseret kewilayah teknis pemilihan penyedia. Sesuai amanah Perpres $54 / 2010$ proses pemilihan penyedia sepenuhnya tanggungjawab Pokja.

3. Pada Tahap Persiapan dan Pelaksanaan Kontrak, Tim PPS dan Bidang Perdata dan Tata Usaha Negara dilibatkan pada tahapan Rapat Persiapan Tanda Tangan Kontrak dan/atau Rapat Persiapan Pelaksanaan Pekerjaan (PCM). Ini penting agar para pihak memahami betul konsekwensi klausula perikatan selain soal teknis, manajemen juga dari sisi hukum perdata. Selaras pula dengan Perpres 54/2010 pasal 86 ayat 1 bahwa PPK wajib melakukan finalisasi kontrak.Secara insidentil PPK meminta pendapat hukum jika diperlukan terkait pengendalian pekerjaan. Jika diperlukan

\footnotetext{
15 Pengaturan Tentang Pengadaan Barang dan jasa sudah diatur mulai Keppres 80 Tahun 2003 kemudian Perpres 54 Tahun 120120 dan terus diubah sampai sekarang.
}

PPK juga dapat meminta pembahasan hukum dari Tim PPS dan Bidang Perdata dan Tata Usaha Negara selama pengendalian kontrak. Misal terkait penanganan kontrak kritis dengan rapat pembuktian atau Show Cause Meeting (SCM).

4. Pada tahap serah terima pekerjaan, kehadiran Tim PPS dan Bidang Perdta dan Tata Usaha Negara dibutuhkan dalam memastikan tidak terdapat permasalahan hukum secara administratif dan keperdataan yang mempengaruhi output pekerjaan dan pemanfaatan hasil.

Tugas Tim PPS dan Bidang Perdata dan Tata Usaha Negara fokus pada pencegahan kebocoran anggaran pada pelaksanaan proyek agar pelaksaan Proyek dapat berjalan dengan baik.

Tugas dan kewenangan Kejaksaan R.I di bidang perdata dan tata usaha negara memiliki landasan hukum yang jelas dan kokoh, sebagaimana tertuang didalam ${ }^{16}$ UndangUndang kejaksaan Pasal 30 Ayat (2) menyebutkan : "Di bidang perdata dan tata Usaha Negara, Kejaksaan dengan kuasa khusus dapat bertindak di dalam maupun di luar pengadilan untuk dan atas nama negara atau pemerintah" Secara berkesinambungan tugas dan fungsi Kejaksaan di bidang perdata ini diatur dalam Undang-Undang Nomor 16 Tahun 2004 tentang Kejaksaan Republik Indonesia, dimana pada Pasal 2 dinyatakan bahwa Kejaksaan mempunyai tugas khusus lain yang diberikan oleh suatu peraturan negara. Tugastugas khusus lain di bidang perdata tersebut yaitu mewakili negara baik di dalam maupun di luar pengadilan Kekuasaan legislatif menegaskan tugas dan fungsi kejaksaan di bidang perdata dan tata usaha negara di dalam Undang-Undang RI Nomor 16 Tahun 2004 tentang Kejaksaan Republik Indonesia, dalam rangka memantapkan kedudukan dan peranan kejaksaan untuk turut serta menjaga dan menegakkan kewibawaan pemerintah dan

\footnotetext{
${ }^{16}$ Undang-Undang Nomor 16 Tahun 2004 tentang Kejaksaan Republik Indonesia, dimana Pasal 30 Ayat (2) yang pada prinsipnya sudah mengatur peran kejaksaan di bidang perdata dan Tata usaha Negara.
} 
negara serta melindungi kepentingan rakyat melalui penegakan hukum. ${ }^{17}$

Bahwa kejaksaan di bidang perdata, sesungguhnya bukanlah hal yang baru karena berdasarkan staatblad Nomor 522 Tahun 1922, kejaksaan diberi tugas dan fungsi di bidang hukum perdata. Bahkan, jauh sebelumnya dalam Burgerlijke wetboek ( Kitab UndangUndang Hukum Perdata) tercantum ketentuan mengenai tugas dan wewenang keperdataan dari kejaksaan, seperti wewenang Kejaksaan untuk mengajukan permohonan kepada pengadilan untuk memerintahkan Balai Harta Peninggalan mengurus harta dan kepentingan orang yang meninggalkan tempat tinggalnya tanpa memberitahukan tempat tinggal baru dan tanpa kabar berita.

\section{B. Bentuk Pengamanan yang dilakukan oleh Bidang Intelijen dalam Proyek Strategis}

Pengamanan dan pengawalan proyek dan mega proyek strategis nasional yang ada didaerah oleh Kejaksaan Republik Indonesia merupakan upaya dalam melakukan pencegahan korupsi oleh penyelengaraan proyek pembangunan dan pihak pihak yang terkait .Upaya Preventif adalah upaya cegah tangkal terjadinya korupsi dalam bentuk pembocoran dana dan pengurangan material yang merugikan Negara. Usaha-usaha yang dilakukan adalah dengan menanamkan nilainilai moral dan kepatuhan seseorang atau perusahan yang menyelengarakan proyek untuk menjauhkan diri dari perbuatan tercela yaitu korupsi. Tindakan awal dapat berupa penyadaran hukum kepada setiap pihak sebagai pelaksana proyek untuk mematuhi hukum dan perundangan yang berlaku. upaya Preventif untuk mencegah dan menangkal embrio timbulnya kejahatan yang pertama kali seperti niat untuk korupsi dan praktik praktik lain yang merugikan Negara dalam pembangunan. Kalau upaya preventif tidak berhasil maka kejaksaan yang memiliki wewenang akan melakukan tindakan represif dalam bentuk penegakan hukum mulai dari penyelidikan, penyidikan dan penuntutan.

\footnotetext{
17 Rakatama Aditya. 2015. Peran Komisi Kejaksaan Sebagai Perwujudan Partisipasi Publik Dalam Rangka Pengawasan Lembaga Kejaksaan. Cetakan kedua. Jakarta: Sinar Grafika. 12
}

Pengamanan kegiatan proyek dan mega proyek pada prinsipnya sebagai Upaya pencegahan kejahatan dapat berarti menciptakan suatu kondisi tertentu agar tidak terjadi kejahatan. Batasan tentang pencegahan kejahatan sebagai suatu usaha yang meliputi segala tindakan yang mempunyai tujuan yang khusus untuk memperkecil ruang atau potensi terjadinya berbagai modus kejahatan dalam proyek $^{18}$.

Pengamanan dan pengawalan proyek pembangunan oleh kejaksaan adalah usahausaha pemberian pengaruh kepada pihak pihak potensial agar jangan melakukan pelanggaran dalam satu kegiatan proyek baik perusahaan atau Konsultan proyek dll. Dasar Hukum pengawalan dan pengamanan pada setiap kegiatan proyek pembangunan Pemerintah yaitu Instruksi Presiden Nomor 7 Tahun 2015 tentang Pencegahan dan Pemberantasan Korupsi. Instruksi Presiden ini dimaksudkan untuk meningkatkan upaya pencegahan terjadinya tindak pidana korupsi di instansi pemerintahan yang perlu didukung dan dilaksanakan secara terencana dan sungguh-sungguh sehingga kegiatan pencegahan korupsi yang dilakukan kejaksaan RI dapat berlangsung efektif dan optimal. Kemudian Instruksi Presiden Nomor 7 tahun 2015 tentang aksi Pencegahan dan Pemberantasan Korupsi Tahun 2015 menjadi dasar pertimbangan dikeluarkannya Keputusan Jaksa Agung Republik Indonesi Nomor: KEP152/A/JA/10/2015 tanggal 1 Oktober 2015 tentang Pembentukan Tim Pengawal dan Pengaman Pemerintahan dan Pembangunan dan Tim Ini telah dibubarkan pada tahun 2019.

Bahwa bentuk pengamanan dan pengawalan Proyek Strategis Nasional yang dilakukan oleh Kejaksaan dibidang Intelijen yaitu lewat penyuluhan hukum dan penerangan hukum terkait pengadaan barang dan jasa Pemerintah yaitu pada tahapan Persiapan Pengadaan, Pelaksanaan Pemilihan Penyedia, Persiapan dan Pelaksanaan Kontrak dan Serah Terima Pekerjaan lewat rapat eveluasi dan pembahasan hukum yang dikuti

\footnotetext{
${ }^{18}$ Yuris Makroni Tri Andraman. 2019. Peran Kejaksaan Sebagai Pengawal Dan Pengaman Pemerintah dan Pembangunan. Jurnal POENALE Hukum Pidana. Vol 7 no 1
} 
oleh Pengguna Barang (Kasatker/Pengguna Anggaran) Penyedia Jasa/kontraktor,Konsultan Pengawas, Konsultan Perencana dengan dengan maksud agar prosedur, mekanisme dan tahapan kegiatan pembangunan dan pemerintahan yang dilaksanakan oleh lingkungan Pemerintah Pusat/Kementerian/ Lembaga/Pemerintah Daerah/BUMN/BUMD, dilakukan sesuai ketentuan peraturan perundang-undangan sehingga proyek tersebut selesai tepat waktu tepat mutu, tepat biaya.

Bahwa berdasarkan Instruksi Presiden No. 7 Tahun 2015 Tentang Aksi Pencegahan Dan Pemberantasan Korupsi tahun 2015. Tim Pengaman Proyek Stragis (PPS) berperan mencegah terjadinya tindak pidana korupsi dengan cara memberikan pendampingan hukum dan melakukan pengamanan pada proyek strategis nasional. Peraturan Jaksa Agung Republik Indonesia Nomor: PER006/A/JA/07/2017 Tentang Organisasi Tata Kerja Kejaksaan Agung R.I dalam Pasal 241 yang menyebutkan salah satu Tugas Seksi Pengamanan Pembangunan Infrastruktur kawasan yaitu menyiapkan perumusan kebijakan teknis Intelijen dan Administrasi Intelijen bahan perencanaan,pengendalian, dan penilaian kegiatan pengawalan dan pengamanan pemerintah dan pembangunan proyek yang bersifat strategis baik nasional maupun daerah yaitu menjaga, mengawal dan memastikan prosedur, mekanisme dan tahapan kegiatan pembangunan dan pemerintahan yang dilaksanakan oleh lingkungan Pemerintah Pusat/Kementerian/ Lembaga/Pemerintah Daerah/BUMN/BUMD, dilakukan sesuai ketentuan peraturan perundang-undangan agar terhindar dari berbagai bentuk hambatan dari pihak-pihak yang berpotensi menghambat atau mengganggu kegiatan pemerintahan dan pembangunan yang akan dan sedang dijalankan, dalam peratuan Jaksa Agung RI tersebut Tim PPS ( Pengaman Proyek Strategis) yaitu Bidang Intelijen yaitu melakukan Pengamanan dan pengawalan sedangkan di Bidang Perdata dan Tata Usaha Negara yaitu melakukan pendampingan hukum atau legal openion untuk mencegah jika terjadi adanya dugaan awal telah terjadi tindak pidana korupsi pada saat diminta untuk dilakukan pengamanan dan pendampingan hukum.

Bahwa berdasarkan Petunjuk Teknis tentang pelaksanaan kegiatan pengamanan dan pembangunan strategis Nomor B-484 /D/Dpp/03/2020 tanggal 12 Maret 2020 yang menegaskan bahwa salah satu tugas dan fungsi Kejaksaan R.I dalam bidang pengamanan pembangunan strategis pada dasarnya dapat dibagi menjadi 2 (dua) antara lain :

A. Intelijen sebagai pengetahuan dilakukan melalui :

a. Inventarisasi dan pengkajian atas peraturan perundang-undangan terkait dengan pemerintahan dan pembangunan yang bersifat strategis dan ;

b. Pemetaan dan analisis masalah yang terkait dengan pemerintahan dan pembangunan yang bersifat strategis untuk mendeteksi dini dan peringatan dini dalam rangka pencegahan, penangkalan, dan penanggulangan terhadap setiap hakekat ancaman yang mungkin timbul dan mengancam keamanan dan kepentingan nasional di bidang pembangunan strategis;

B. Intelijen sebagai Aktivitas dilakukan melalui :

a. Koordinasi dan kerja sama dengan kementrian/ Lembaga dan pemerintah daerah dan organisasi lain yang berkaitan dengan pengamanan pembangunan strategis;

b. Pengkajian dengan aparat pengawas internal pemerintah dalam hal penilaian kebijakan yang dilakukan oleh pelaksana kegiatan;

c. Melakukan penyuluhan Hukum dan Penerangan hukum dan atau;

d. Pelaksanaan fungsi penyelidikan (LID) Pegamanan (PAM), Penggalangan (GAL) lainya sesuai fungsi intelijen penegakan hukum untuk mendeteksi dini dan peringatan dini dalam rangka pencegahan, penangkalan, dan penanggulangan terhadap setiap hakekat ancaman yang mungkin timbul dan mengancam keamanan 
dan kepentingan nasional di bidang pembangunan strategis;

Bahwa untuk mencegah terjadinya penyimpangan yang berpotensi menghambat, menggagalkan dan menimbulkan kerugian bagi keuangan negara, Tim PPS Intelijen melakukan Koordinasi dengan APIP dan/atau instansi terkait dalam hal ini penyidik PPNS di Pemerintah Daerah.

Bahwa Tim Pengamanan Pemerintahan dan Pembangunan harus terus dilanjutkan oleh pihak kejaksaan Walaupun Tim Pengawalan Pengamanan Dan Pendampingan Pembangunan Daerah TP4D sudah dibubarkan, fungsi kejaksaan Pemberantasan korupsi dan penegakan hukum harus terus dijalankan melalui berbagai upaya pencegahan dini berbagai skandal dalam proyek antara pengusaha pemerintah serta pihak terafiliasi lainya yang merugikan keuangan Negara. Karena pada prinsipnya setiap proyek pembangunan ditujukan untuk kesejahtraan rakyat. kejaksaan sebagai lembaga penegak hukum harus berperan dalam mengawal dan mengawasi penyelenggaraan proyek pembangunan, agar tepat biaya, tepat waktu dan tepat mutu. Pengawalan dan pengamanan baik dalam kegiatan perencanaan, pelaksanaan maupun pemanfaatan hasil pembangunan, termasuk dalam upaya mencegah timbulnya penyimpangan dan kerugian Negara. Pengawalan dan Pengamanan proyek Pembangunan oleh Kejaksaan Republik Indonesia dibentuk untuk melakukan pendampingan pada kegiatan proyek pembangunan baik yang akan maupun sedang dilaksanakan sesuai ketentuan hukum yang berlaku. Tidak adanya pengamanan dan pengawalan kejaksaan dalam proyek pembangunan di daerah akan memperbesar potensi dan peluang untuk terjadinya korupsi. Selama ini para pejabat pemerintah dalam menggunakan anggaran sering ragu-ragu dalam mengambil tindakan atau kebijakan karena takut tersandung kasus korupsi, sehingga penyerapan anggaran rendah yang berimplikasi pada kinerja dan pembangunan yang tidak maksimal. Mencegah terjadinya tindak pidana korupsi dan mendorong pelaksanaan pembangunan di daerah maka sejak dini perlu dilakukan pendampingan terhadap pejabat pemerintah terkait pengelolaan anggaran dan pelaksanaan program-program pembangunan. Indonesia sebagai Negara hukum (Rechtsstaat) bermakna bahwa di dalam Negara Kesatuan RI, hukum merupakan urat nadi seluruh aspek kehidupan.

Dalam Undang Undang No.16 Tahun 2004 tentang Kejaksaan RI, Pasal 2 ayat (1) menegaskan bahwa Kejaksaan RI adalah lembaga pemerintah yang melaksanakan kekuasaan negara dalam bidang penuntutan serta kewenangan lain berdasarkan undangundang. Kejaksaan sebagai pengendali proses perkara (Dominus Litis), Kejaksaan mempunyai kedudukan sentral dalam penegakan hukum, karena hanya institusi Kejaksaan yang dapat menentukan apakah suatu kasus dapat diajukan ke Pengadilan atau tidak berdasarkan alat bukti yang sah menurut Hukum Acara Pidana. Terkait dengan pecegahan korupsi dan menegakan supremasi hukum dalam kehidupan berbangsa dan bernegara, serta dapat berfungsi menjadi tulang punggung reformasi, Kedudukan sentral Kejaksaan berkait dengan pemberantasan korupsi dan pencegahan dalam berbagai penyimpangan dalam proyek harus terus diperkuat.

\section{PENUTUP}

\section{A. Kesimpulan}

1. Pendampingan hukum kejaksaan terkait dengan fungsi keperdataan dan salah satu ruang lingkup di Bidang Perdata dan Tata Usaha Negara meliputi Penegakan hukum,bantuan hukum, pertimbangan hukum dan tindakan hukum lainnya kepada negara atau pemerintah meliputi lembaga negara atau badan negara atau instansi pemerintah dan daerah, Badan Hukum Milik Negara (BUMN) atau Daerah (BUMD) di Bidang Perdata dan Tata Usaha Negara untuk menyelamatkan,memulihkan kekayaan negara, menegakan kewibawaan pemerintah dan negara serta memberikan pelayanan hukum kepada masyarakat, Pendampingan hukum secara perdata adalah upaya pencegahan tindak pidana korupsi yang efisien dan efektif dapat dilakukan dengan 4 (empat) pendekatan atau strategi yaitu: 1 . Pendekatan hukum; 2. 
Pendekatan budaya 3. Pendekatan ekonomi 4. Pendekatan sumber daya manusia dan sumber daya keuangan.

2. Pengawalan dan Pengamanan oleh Kejaksaan terkait dengan Fungsi kejaksaan di Bidang Intelijen yaitu penyelidikan, pengamanan dan penggalangan dan Penegakan Hukum khususnya dalam melakukan pencegahan terjadinya tindak pidana korupsi pada pelaksanaan Proyek Strategis, Pengawalan dan pengamanan yang di lakukan oleh bidang Intelijen merupakan upaya untuk melakukan pencegahan agar pelaksanaan proyek tersebut dilaksanakan sesuai ketentun perundang-undangan yang berlaku yaitu tepat mutu,tepat waktu dan tepat biaya agar manfaatnya bisa dirasakan oleh masyarakat, Negara dan bangsa Indonesia.dengan pengawalan dan pengamanan terhadap proyek yang dilakukan oleh Kejaksaan maka potensi terjadinya tindak pidana korupsi dapat di minimalisir dengan pendekatan preventif maka peluang terjadinya penyalagunaan anggaran Negara yang dilakukan oleh penyedia jasa,Penyelenggara proyek diinstansi Pemerintah dalam proyek bisa ditekan, demi terwujudnya masyarakat adil dan makmur.

\section{B. Saran}

1. Pengamanan di Bidang Intelijen dan Pendampingan hukum di Bidang Perdata dan Tata Usaha Negara yang dilakukan oleh Institusi Kejaksaan R.I terhadap pelaksanaan proyek Strategis sangat diperlukan untuk mengawasi anggaran proyek baik anggarannya berumber APBN/APBD guna mewujudkan tata kelolah Pemerintah yang baik agar pelaksaan proyek tersebut dapat terlaksana dengan baik dalam arti tidak ada pihak-pihak yang akan menghalanghalangi atau menggagalkan proyek tersebut, dengan demikian pekerjaan proyek tersebut akan selesai tepat waktu, tepat mutu sehingga dampak positif yang dirasakan oleh masyarakat dan negara sangat besar karena uang negara dikelolah dengan baik dan kegiatan pembangunan selesai tepat waktu.

2. Bahwa untuk melaksanakan instruksi Presiden Nomor: 07 tahun 2015 tentang Aksi Pencegahan dan Pemberantasan Tindak Pidana Korupsi, maka harus ada keseriusan lembaga Pemerintah baik pusat maupun daerah guna mewujudkan tata kelola pemerintahan yang baik (good governance) diantaranya prinsip transparansi dan akuntabilitas dalam mengelolah keuangan Negara, serta memiliki pemahaman, kecermatan dan ketelitian yang baik terhadap setiap peraturan yang ada dan ini merupakan kunci terselenggaranya pengelolaan keuangan yang baik oleh karena itu Kejaksaan Republik Indonesia sebagai lembaga negara harus mampu memberikan pemahaman dan memberikan penyuluhan hukum kepada instansi Pemerintah baik BUMN dan BUMD untuk mengelolah keuangannya dengan baik berdasarkan peraturan perundangundang yang berlaku.

\section{DAFTAR PUSTAKA}

Abdulkadir Muhamad. 2010. Hukum Perusahan Indonesia. Cetakan Ketiga. Bandung: Cv Citra Adytia Bhakti.

Sri Soemantri.1992. Bunga Rampai Hukum Tata Negara Indonesia. Cetakan Ketiga. Bandung:Alumni.

Harun Alrasid. 2007.Judul Naskah UndangUndang Dasar 1945 Sesudah Empat Kali Diubah oleh MPR. Cetakan pertama. Jakarta: UI Press.

M Gaffar.2003.Budaya Hukum dalam Penegakan Hukum. Cetakan pertama. Bandung: Sinar Grafika.

Fuady Munir.1996. Hukum Bisnis Dalam Teori dan Praktek. Cetakan pertama. Bandung: Citra Aditya Bakti. 20

Amiruddin. 2010. Pengantar Metode Penelitian Hukum. Cetakan Ketiga. Jakarta: Rajawali Pers.

Munir Fuady. 1998. Kontrak Pemborongan Mega Proyek. Cetakan pertama. Jakarta: PT. Citra Aditya Bakti. 
Arsyad Jawada Hafids. 2003. Korupsi dalam Perspektif Hukum Administrasi Negara. Cetakan Jakarta: Pertama Sinar Grafika. Cetakan Pertama.

Yasin. Nazarkhan. 2006. Mengenal Kontrak Konstruksi di Indonesia. Cetakan pertama. Jakarta: PT Gramedia Pustaka Utama. 43

Rakatama Aditya. 2015. Peran Komisi Kejaksaan Sebagai Perwujudan Partisipasi Publik Dalam Rangka Pengawasan Lembaga Kejaksaan.Cetakan kedua. Jakarta: Sinar Grafika.

Yuris Makroni Tri Andraman. 2019. Peran Kejaksaan Sebagai Pengawal Dan Pengaman Pemerintah dan Pembangunan. Jurnal POENALE Hukum Pidana. Vol 7 no 1 